Nevada

Environmental

Restoration

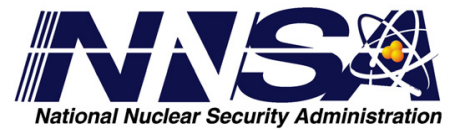

Project

\title{
Addendum to the Closure Report for Corrective Action Unit 322: Areas 1 \& 3 Release Sites and Injection Wells Nevada Test Site, Nevada
}

Controlled Copy No::

Revision No.: 0

October 2008

Approved for public release; further dissemination unlimited.

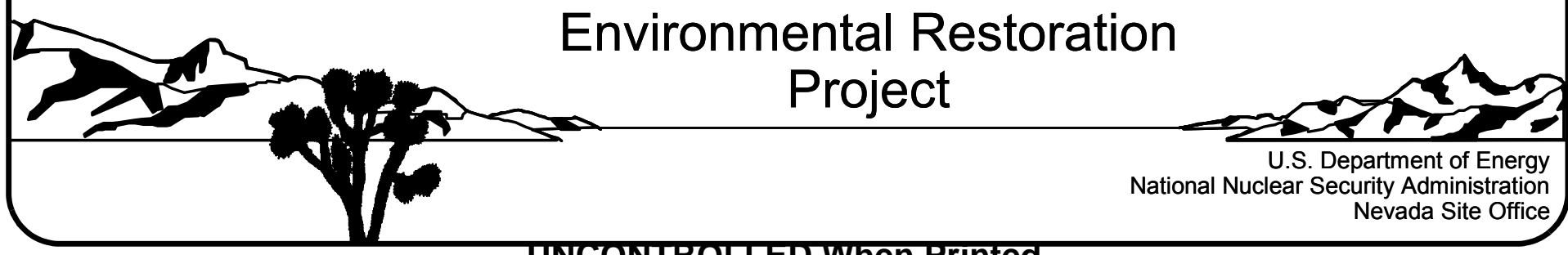


Available for public sale, in paper, from:

U.S. Department of Commerce

National Technical Information Service

5285 Port Royal Road

Springfield, VA 22161

Phone: 800.553 .6847

Fax: 703.605.6900

Email: orders@ntis.gov

Online ordering: http://www.ntis.gov/ordering.htm

Available electronically at $\underline{h t p: / / w w w . o s t i . g o v / b r i d g e ~}$

Available for a processing fee to U.S. Department of Energy and its contractors, in paper, from:

U.S. Department of Energy

Office of Scientific and Technical Information

P.O. Box 62

Oak Ridge, TN 37831-0062

Phone: 865.576 .8401

Fax: 865.576.5728

Email: reports@adonis.osti.gov

Reference herein to any specific commercial product, process, or service by trade name, trademark, manufacturer, or otherwise, does not necessarily constitute or imply its endorsement, recommendation, or favoring by the United States Government or any agency thereof or its contractors or subcontractors. 


\title{
ADDENDUM TO THE CLOSURE REPORT FOR CORRECTIVE ACTION UNIT 322: AREAS 1 \& 3 RELEASE SITES AND INJECTION WELLS NEVADA TEST SITE, NEVADA
}

\author{
U.S. Department of Energy \\ National Nuclear Security Administration \\ Nevada Site Office \\ Las Vegas, Nevada
}

Controlled Copy No.:

Revision No.: 0

October 2008

Approved for public release; further dissemination unlimited. 


\section{Addendum to the Closure Report for Removal of the Use Restriction}

This document constitutes an addendum to the June 2006, Closure Report for Corrective Action Unit 322: Areas 1 \& 3 Release Sites and Injection Wells as described in the document Recommendations and Justifications for Modifications for Use Restrictions Established under the U.S. Department of Energy, National Nuclear Security Administration Nevada Site Office Federal Facility Agreement and Consent Order (UR Modification document) dated February 2008. The UR Modification document was approved by NDEP on February 26, 2008. The approval of the UR Modification document constituted approval of each of the recommended UR modifications. In conformance with the UR Modification document, this addendum consists of:

- This cover page that refers the reader to the UR Modification document for additional information

- The cover and signature pages of the UR Modification document

- The NDEP approval letter

- The corresponding section of the UR Modification document

This addendum provides the documentation justifying the cancellation of the URs for:

- CAS 01-25-01, AST Release

- CAS 03-25-03, Mud Plant AST Diesel Release

These URs were established as part of Federal Facility Agreement and Consent Order (FFACO) corrective actions and were based on the presence of contaminants at concentrations greater than the action levels established at the time of the initial investigation (FFACO, 1996; as amended August 2006).

Since these URs were established, practices and procedures relating to the implementation of risk-based corrective actions (RBCA) have changed. Therefore, these URs were re-evaluated against the current RBCA criteria as defined in the Industrial Sites Project Establishment of Final Action Levels (NNSA/NSO, 2006c). This re-evaluation consisted of comparing the original data (used to define the need for the URs) to risk-based final action levels (FALs) developed using the current Industrial Sites RBCA process.

The re-evaluation resulted in a recommendation to remove these URs because contamination is not present at these sites above the risk-based FALs. Requirements for inspecting and maintaining these URs will be canceled, and the postings and signage at each site will be removed. Fencing and posting may be present at these sites that are unrelated to the FFACO URs such as for radiological control purposes as required by the NV/YMP Radiological Control Manual (NNSA/NSO, 2004f). This modification will not affect or modify any non-FFACO requirements for fencing, posting, or monitoring at these sites. 
Nevada

Environmental

Restoration

Project

Recommendations and Justifications for Modifications for Use Restrictions Established under the U.S. Department of Energy, National Nuclear Security Administration Nevada Site Office

Federal Facility Agreement and Consent Order

Controlled Copy No.:

Revision No.: 0

February 2008

Approved for public release; further dissemination unlimited.

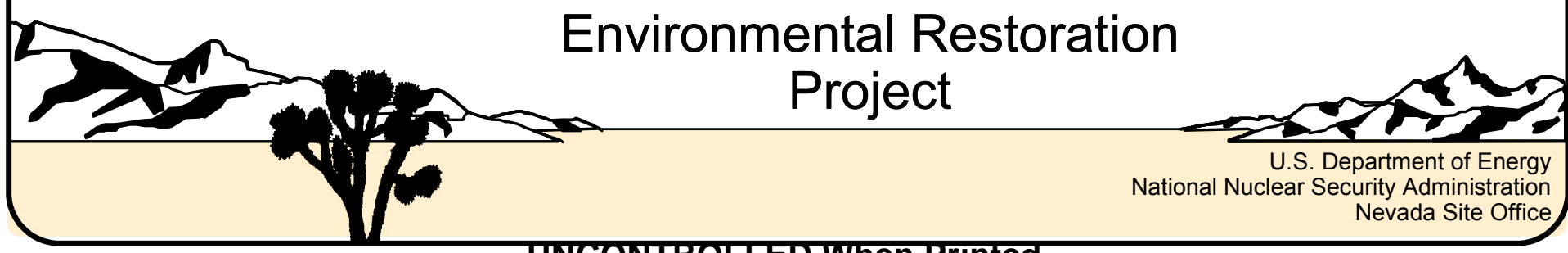


Recommendations and Justifications for Modifications for Use Restrictions Established under the U.S. Department of Energy, National Nuclear Security Administration Nevada Site Office Federal Facility Agreement and Consent Order

Approved by: /s/ Kevin J. Cabble

Date: $02 / 05 / 2008$

Kevin J. Cabble

Federal Sub-Project Director

Industrial Sites Sub-Project

Approved by:

/s/ John B. Jones

Date: $02 / 04 / 2008$

John B. Jones

Acting Federal Project Director

Environmental Restoration Project 
February 26, 2008

John B. Jones

Acting Federal Project Director

Environmental Restoration Project

National Nuclear Security Administration

Nevada Site Office

P. O. Box 98518

Las Vegas, NV 89193-8518

RE: Approval of Recommendations and Justifications for Modifications for Use Restrictions

Established under the U.S. Department of Energy, National Nuclear Security Administration, Nevada Site Office Federal Facility Agreement and Consent Order

Dear Mr. Jones:

The Nevada Division of Environmental Protection, Bureau of Federal Facilities (NDEP) staff has received and reviewed the February 2008 final report for Recommendations and Justifications for Modifications for Use Restrictions Established under the U.S. Department of Energy, National Nuclear Security Administration, Nevada Site Office. The NDEP approves the requested changes to the previously agreed upon use restrictions for those Corrective Action Sites (CASs) as described in the report.

Address any questions regarding this matter to either Ted Zaferatos at (702) 486-2850, ext. 234 , or me at (702) 486-2850, ext. 231.

Sincerely

\section{/s/ Tim Murphy}

\section{T.H. Murphy}

Chief

Bureau of Federal Facilities

$\mathrm{TZ}$

cc: $\quad$ E.F. DiSanza, WMP, NNSA/NSO

FFACO Group, PSG, NNSAINSO, Las Vegas, NV

David C. Loewer, DTRAVCXT1, M/S 645, Mercury, NV

W.R. Griffin, SNJV/DTRA, M/S 645, Mercury, NV

T.A. Thiele, NSTec, Las Vegas, NV

R.F. Boehlecke, SNJV, Las Vegas, NV

K. J. Cabble, ERP, NNSANSO, Las Vegas, NV

John Wong. Jeff MacDougall, Dennis Nicodemus, NDEP Las Vegas, NV 


\subsection{CAU 322, CAS 01-25-01 - AST Release}

\subsection{CAS Description}

The former aboveground storage tank (AST) is located in Area 1, within the boundaries of the Shaker Plant, in the northern portion of plant grounds. The AST was located within a berm constructed of earth and gravel, and the berm floor contains several pieces of large wooden plyboard used for tank support. Additional pieces of heavy railroad ties were discovered under the berm floor surface during excavation. The berm once contained a 10,000-gal diesel fuel AST, which was relocated approximately $40 \mathrm{ft}$ southeast of the CAS. The AST provided fuel for the operation of the Shaker Plant (NNSA/NSO, 2004e).

\subsection{Current Use Restriction Description}

The future use of any land affected by this UR is restricted from any DOE or Air Force activity that may alter or modify the containment control, as approved by the state and identified in the CAU CR or other CAU documentation, unless appropriate concurrence is obtained in advance. As part of closure activities, fencing was erected around the rectangular AST berm to limit access to the interior of the berm, and four UR signs were posted around the perimeter of the berm. Site monitoring requirements for the UR include periodic visual inspections of UR postings and fencing. These are required annually for the first five years, followed by every five years, for a total of 30 years (NNSA/NSO, 2006b).

\subsection{Basis for Current Use Restriction}

Samples were analyzed for TPH (DRO and GRO), total VOCs, total SVOCs, total RCRA metals, total beryllium, PCBs, and gamma spectroscopy. Except for TPH-DRO, all other COPCs were detected below their PALs, including VOCs and SVOCs. Concentrations of TPH-DRO exceeding the PAL of $100 \mathrm{mg} / \mathrm{kg}$ were detected at both sampling locations (NNSA/NSO, 2004e).

Table 9-1 contains analytical results of all COCs at CAS 01-25-01 that are the basis for the current UR. The sample matrix for all samples is soil. 
Table 9-1

Sample Results for COCs at CAS 01-25-01

Used To Establish Current Use Restriction

\begin{tabular}{|c|c|c|c|}
\hline \multirow{2}{*}{$\begin{array}{l}\text { Sample } \\
\text { Location }\end{array}$} & \multirow[b]{2}{*}{ Sample ID } & \multirow{2}{*}{$\begin{array}{l}\text { Depth } \\
\text { (ft bgs) }\end{array}$} & TPH (DRO) \\
\hline & & & $\begin{array}{c}\text { PAL } \\
100 \mathrm{mg} / \mathrm{kg}\end{array}$ \\
\hline \multirow{2}{*}{$\mathrm{A} 01$} & 322A001 & $0-0.5$ & 2,900 (J) \\
\hline & 322A002 & $2-3$ & $480(\mathrm{D})$ \\
\hline \multirow{6}{*}{$\mathrm{A} 02$} & $322 \mathrm{~A} 003$ & $0-0.5$ & 5,900 (J) \\
\hline & $322 \mathrm{~A} 004$ & $2-3$ & 7,000 (J) \\
\hline & 322A005 & $2-3$ & 6,900 (D) \\
\hline & 322A009 & $4-5$ & 6,700 (D) \\
\hline & $322 \mathrm{~A} 010$ & $6-7$ & $1,100(D)$ \\
\hline & $322 \mathrm{~A} 011$ & $9-10$ & $140(\mathrm{D})$ \\
\hline \multicolumn{2}{|c|}{$\begin{array}{l}\text { bgs = Below ground surface } \\
\text { DRO = Diesel-range organics } \\
\mathrm{ft}=\text { Foot }\end{array}$} & \multicolumn{2}{|c|}{$\begin{array}{l}\mathrm{mg} / \mathrm{kg}=\text { Milligrams per kilogram } \\
\mathrm{PAL}=\text { Preliminary action level } \\
\mathrm{TPH}=\text { Total petroleum hydrocarbons }\end{array}$} \\
\hline
\end{tabular}

\subsection{Basis for Use Restriction Modification}

The revised FALs associated with the TPH contamination were established based on the PALs of hazardous constituents of TPH diesel as described in Section 2.2.2. Hazardous constituents of TPH diesel were not detected in any of the samples at concentrations greater than their respective PALs (NNSA/NSO, 2004e). Therefore, no contaminants are present at this site in concentrations exceeding the revised FALs, and all revised FALs were established at the PAL concentrations.

\subsection{Proposed Modification}

Remove the FFACO UR, associated fencing and postings, and inspection and maintenance requirements from this site. 


\subsection{CAU 322, CAS 03-25-03 - Mud Plant AST Diesel Release}

\subsection{CAS Description}

Corrective Action Site 03-25-03 is located within the former Mud Plant facility in the former Area 3 Camp. The Mud Plant facility began operation in February 1962 and was used to formulate mud mixtures in support of drilling operations for the UGTA Project. The Mud Plant facility operations ceased in December 1995. An AST containing fuel oil and a fuel dispensing station were located approximately $350 \mathrm{ft}$ west of the Mud Plant. Available records indicated the AST had a capacity of approximately 10,000 gal and was located in a gravel containment pit. Aerial photos indicate the fuel dispensing station was located south of the AST. Information was not available regarding the type of equipment or physical condition of the fuel dispensing station. The AST and fuel station were removed; however, the date of the removal is not available (NNSA/NSO, 2003f).

\subsection{Current Use Restriction Description}

The future use of any land affected by this UR is restricted from any DOE or Air Force activity that may alter or modify the containment control, as approved by the state and identified in the CAU CR or other CAU documentation, unless appropriate concurrence is obtained in advance. As part of closure activities, fencing was erected along the Mud Plant boundary, connecting with existing fencing surrounding the Mud Plant Pond and Mud Disposal Crater to limit access to the interior of the contaminated area, and six UR signs were installed around the impacted area between the Mud Plant, Mud Plant Pond, and Mud Disposal Crater. Site monitoring requirements for the UR include periodic visual inspections of UR postings and fencing. These are required annually for the first five years, followed by every five years, for a total of 30 years. (NNSA/NSO, 2006b)

\subsection{Basis for Current Use Restriction}

Samples were analyzed for TPH (DRO and GRO), total VOCs, total SVOCs, total RCRA metals, $\mathrm{PCBs}$, total beryllium, isotopic $\mathrm{U}$, isotopic $\mathrm{Pu}, \mathrm{Sr}-90$, and gamma spectroscopy. Except for TPH-DRO, all other COPCs were detected below their PALs, including VOCs and SVOCs. Concentrations of TPH-DRO exceeding the PAL of $100 \mathrm{mg} / \mathrm{kg}$ were detected at six sampling locations (NNSA/NSO, 2004e). 
Table 10-1 contains analytical results of all COCs at CAS 03-25-03 that are the basis for the current UR. The sample matrix for all samples is soil.

Table 10-1

Sample Results for COCs at CAS 03-25-03

Used To Establish Current Use Restriction

\begin{tabular}{|c|c|c|c|c|}
\hline \multirow{2}{*}{$\begin{array}{l}\text { Sample } \\
\text { Location }\end{array}$} & \multirow[b]{2}{*}{ Area } & \multirow[b]{2}{*}{ Sample ID } & \multirow{2}{*}{$\begin{array}{l}\text { Depth } \\
\text { (ft bgs) }\end{array}$} & TPH (DRO) \\
\hline & & & & $\begin{array}{c}\text { PAL } \\
100 \mathrm{mg} / \mathrm{kg}\end{array}$ \\
\hline B01 & \multirow{2}{*}{ A } & 322B038 & $2-3$ & $140(\mathrm{D}, \mathrm{H}, \mathrm{M})$ \\
\hline B04 & & 322B010 & $0-0.5$ & $370(\mathrm{H}, \mathrm{M})$ \\
\hline B08 & \multirow{5}{*}{ B } & 322B053 & $2-3$ & $170(\mathrm{H}, \mathrm{M})$ \\
\hline B14 & & 322B043 & $14-15$ & $300(\mathrm{H}, \mathrm{Y})$ \\
\hline \multirow{2}{*}{ B15 } & & 322B020 & $0-0.5$ & $150(\mathrm{H}, \mathrm{M})$ \\
\hline & & 322B044 & $2-3$ & $4,000(\mathrm{Y})$ \\
\hline B17 & & 322B062 & $2-3$ & $1,500(\mathrm{H}, \mathrm{M})$ \\
\hline
\end{tabular}

bgs $=$ Below ground surface

$\mathrm{DRO}=$ Diesel-range organics

$\mathrm{mg} / \mathrm{kg}=$ Milligrams per kilogram

$\mathrm{ft}=$ Foot

$\mathrm{PAL}=$ Preliminary action level

ID = Identification

$\mathrm{TPH}=$ Total petroleum hydrocarbons

$\mathrm{D}=\mathrm{A}$ pattern resembling diesel was detected in the samples.

$\mathrm{H}=$ The fuel pattern was in the heavier end of the retention time window for the analyte of interest.

$\mathrm{M}=\mathrm{A}$ pattern resembling motor oil was detected.

$\mathrm{Y}=$ Multipeak chromatogram does not match target analytes.

\subsection{Basis for Use Restriction Modification}

The revised FALs associated with the TPH contamination were established based on the PALs of hazardous constituents of TPH diesel described in Section 2.2.2. Hazardous constituents of TPH diesel were not detected in any of the samples at concentrations greater than their respective PALs (NNSA/NSO, 2004e). Therefore, no contaminants are present at this site in concentrations exceeding the revised FALs, and all revised FALs were established at the PAL concentrations.

\subsection{Proposed Modification}

Remove the FFACO UR, associated fencing and postings, and inspection and maintenance requirements from this site. 


\section{References}

FFACO, see Federal Facility Agreement and Consent Order.

Federal Facility Agreement and Consent Order. 1996 (as amended). Agreed to by the State of Nevada; U.S. Department of Energy, Environmental Management; U.S. Department of Defense; and U.S. Department of Energy, Legacy Management.

NNSA/NSO, see U.S. Department of Energy, National Nuclear Security Administration Nevada Site Office.

U.S. Department of Energy, National Nuclear Security Administration Nevada Site Office. 2003f. Corrective Action Investigation Plan for Corrective Action Unit 322: Areas 1 and 3 Release Sites and Injection Wells, Nevada Test Site, Nevada, Rev. 0, DOE/NV--901. July. Las Vegas, NV.

U.S. Department of Energy, National Nuclear Security Administration Nevada Site Office. 2004e. Corrective Action Decision Document for Corrective Action Unit 322: Areas 1 and 3 Release Sites and Injection Wells Nevada Test Site, Nevada, Rev. 0, DOE/NV--1023. December. Las Vegas, NV.

U.S. Department of Energy, National Nuclear Security Administration Nevada Site Office. 2004f. NV/YMP Radiological Control Manual, DOE/NV--11718-079, Rev. 5. Prepared by Bechtel Nevada. Las Vegas, NV.

U.S. Department of Energy, National Nuclear Security Administration Nevada Site Office. 2006b. Closure Report for Corrective Action Unit 322: Areas 1 and 3 Release Sites and Injection Wells, Nevada Test Site, Nevada, Rev. 0, DOE/NV--1134. June. Las Vegas, NV.

U.S. Department of Energy, National Nuclear Security Administration Nevada Site Office. 2006c. Industrial Sites Project Establishment of Final Action Levels, Rev. 0, DOE/NV--1107. Las Vegas, NV. 


\title{
Library Distribution List
}

\author{
$\underline{\text { Copies }}$ \\ U.S. Department of Energy \\ 1 (Uncontrolled, electronic copy) \\ National Nuclear Security Administration \\ Nevada Site Office \\ Technical Library \\ P.O. Box 98518, M/S 505 \\ Las Vegas, NV 89193-8518 \\ U.S. Department of Energy \\ Office of Scientific and Technical Information \\ 1 (Uncontrolled, electronic copy) \\ P.O. Box 62 \\ Oak Ridge, TN 37831-0062 \\ Southern Nevada Public Reading Facility \\ 2 (Uncontrolled, electronic copies) \\ c/o Nuclear Testing Archive \\ P.O. Box 98521, M/S 400 \\ Las Vegas, NV 89193-8521 \\ Manager, Northern Nevada FFACO \\ 1 (Uncontrolled, electronic copy) \\ Public Reading Facility \\ c/o Nevada State Library \& Archives \\ 100 N Stewart Street \\ Carson City, NV 89701-4285
}

